http://artnodes.uoc.edu

\title{
ARTICLE
}

\section{NEW MEDIA, ART-SCIENCE AND CONTEMPORARY ART: TOWARDS A HYBRID DISCOURSE?}

\section{Could This Be What It Looks Like? Lifelike Art and Art-and-Technology Practice}

\author{
Jamie Allen \\ Culture Lab \\ Newcastle University
}

Submission date: June, 2011

Accepted date: September, 2011

Published in: November, 2011

\begin{abstract}
For more than ten years, a number of archival and curatorial projects have mapped out a trajectory of art-historical roots for the values and practices of new media arts, its conventions and institutions. These accounts are, as often as not, earnest attempts made by practitioners and theorists alike to "save" new media's artists and works from the purported inevitability of becoming a ghettoized subculture, walled off from the resources and distribution channels associated with Western contemporary (and commercial) museum and gallery culture. Saving new media in this way purportedly holds the promise of improving critical discourse surrounding "the work", developing audience and interest, stimulating economic potential, and securing new media its rightful detent as another lineal "movement" in histories of creative practice.

The experimental, process-driven and often anti-professional outlook of the conceptual avant-garde of the latter half of the 20th century provides an oft-cited and somewhat contradictory framework for situating new media within a contemporary art system that has remained relatively formal. As well, the current proliferation, popularization and extension of abilities that only a decade ago were the exclusive purvey of self-proclaimed new media artists have resulted in a number of points of entry for non-specialists to access concepts in non-objective art, participatory performance, process and systems-art. Is the dream of the early techno-artistic avant-garde becoming a reality?
\end{abstract}

\section{Keywords}

new media, digital, interactive, histories, genealogy, contemporary, art, worlds 


\title{
artnodes
}

http://artnodes.uoc.edu

Could This Be What It Looks Like? Lifelike Art...

\author{
¿Y si esto es lo que parece? \\ Arte que imita la vida y práctica artística tecnológica
}

\begin{abstract}
Resumen
Desde hace más de diez años, diversos proyectos de archivo y comisariado se han dedicado a rastrear las raíces artístico-históricas de los valores y prácticas del arte de los nuevos medios, sus convenciones e instituciones. Estas descripciones constituyen, con bastante frecuencia, esfuerzos concienzudos por parte tanto de artistas como de teóricos por "evitar» que obras y artistas de los nuevos medios se conviertan, en teoría inevitablemente, en una subcultura segregada, aislada de los recursos y canales de distribución asociados con la cultura contemporánea (y comercial) occidental de museos y galerías. Se supone que la salvación de los nuevos medios en estos términos promete asimismo mejorar el discurso crítico en torno a "la obra", generar un público y un interés, estimular el potencial económico y garantizarles su legitimidad como otro «movimiento» lineal sumado a las demás historias de la práctica creativa.

La perspectiva experimental, a menudo antiprofesional y procesal, de la vanguardia conceptual desarrollada en la segunda mitad del siglo xx proporciona un marco muy habitual y un tanto contradictorio para situar los nuevos medios dentro de un sistema de arte contemporáneo que ha permanecido relativamente convencional. Asimismo, la proliferación, popularización y extensión actual de aptitudes que tan sólo hace una década parecían restringirse a los autoproclamados artistas de los nuevos medios han generado diversos puntos de acceso para no especialistas a los conceptos de arte no objetivo, performance participativa, arte de procesos y sistemas. ¿Se está haciendo realidad el sueño de la primera vanguardia técnico-artística?
\end{abstract}

\section{Palabras clave}

nuevos medios, digital, interactivo, historias, genealogía, contemporáneo, arte, mundos

\section{Introduction}

A homemade music video for Gil Scott-Heron's famous anticonsumerist song The Revolution Will Not Be Televised on YouTube stands as a handy distillation of relations in the rhetorics and realities of contemporary art, technologised art practice and popular culture (craninthebrave, 2009). With Gil Scott-Heron, the quintessential antiestablishment "black Bob Dylan" (Smith 2009), we are reminded of how many of our current notions of the role of the avant-garde begin with the ideas of 1960s counterculture. The use of YouTube as delivery channel for a visual complement to the original audio track situates it within an unexceptional barrage of browser icons, banner ads and metadata clutter. The lyrics of the song, belittling as they do advertising and television culture ("The revolution will not 'Go better with Coke'"), make you wonder how pleased the Scott-Heron of 1970 would be to see his creation juxtaposed in this way, even if it includes a link to "Download this Song: AmazonMP3 iTunes". The maker of the YouTube segment, user "crinanthebrave", effortlessly manifests the potential of current technology to collocate and recreate our visual archive at will. The video - presumably brought into the world with few concerns for audience, form, context, or recognition - articulates a now-familiar breakdown between producer and consumer (to say nothing of the "comments" facility). And all the while Scott-Heron's text calls forth a revolution outside of cycles of production and consumption, giving way to a culture where, as artist Allan Kaprow suggested, we all embody a "sophistication of consciousness in the arts" in our everyday lives (Kaprow, 1971).

\section{Best laid plans of gerbils and men}

Art-and-technology practice and discourse ("new media," "digital art," and "interactive art"), are most often historicised as having been deeply influenced by the motivations of 1960s and 1970s artistic counterculture (Wardrip-Fruin et al., 2003). Artists linked to Fluxus, including Kaprow, Dick Higgins, Nam June Paik and related thinkers and makers, themselves influenced by Cage's taking up of McLuhan and Fuller, were among the first to explore technologies as part of processes challenging artistic convention. Fluxus and other countercultural artistic tendencies developed understandings of artistic freedom that led to a number of non-art, anti-form and performative practices employing technology, inside and outside the gallery. For 


\section{artnodes}

http://artnodes.uoc.edu

Could This Be What It Looks Like? Lifelike Art...

example, Kaprow's Hello (1969), multiplexed five television cameras with twenty-seven closed circuit monitors in public spaces to allow people in different locations in Boston to make contact with each other (Youngblood, 1970). The result was a progressive fusion of conceptual art and technological progressivism — a techno-artistic avant-garde. These early groups saw in "all this electronic information [that] has no weight, no gravity" (Paik, 1985) opportunities for a questioning of the material in the immaterial, the located in the distributed.

Jack Burnham's writings on art-and-technology of this period set out a more structured account "rooted in the concerns of his contemporaries" (Rampley, 2005) and developed through Systems Theory. Burnham held that systems and cybernetics were in fact a catalyst for conceptual, anti-form and anti-object ideas in art. He writes, "[The] cultural obsession with the art object is slowly disappearing and being replaced by what might be called 'systems consciousness.' Actually, this shift from the direct shaping of matter to a concern for organising quantities of energy and information [...]" (Burnham 1968). Software, Information Technology: Its New Meaning for Art curated by Burnham at the Jewish Museum in New York City (1970) seems to many (including Shanken, 1999; Penny, 1999; Gere, 2005; and Skrebowski, 2006) at once a first great triumph and a great failure of early art-and-technology communities working with the mainstream art world. The exhibition included a number of seminal pieces that used new technologies in ways that reflected the impact of electronics and information systems on art, as well as other social structures and consciousness itself. Nicholas Negroponte's contribution was "Seek, a computer-controlled robotic environment that, at least in theory, cybernetically reconfigured itself in response to the behaviour of the gerbils that inhabited it" (Shanken, 1999).

Fred Turner (2006) charts a further intermingling of information technologies and countercultures that would challenge the status quo of the late 1960s, focusing on Stewart Brand, founding editor of the Whole Earth Catalog (WE), an alternative cultural almanac first published in 1968. Brand was instrumental in shaping social cultures of computing and digital creativity. The WE office in Menlo park was host to both Stanford University engineers, working on the early internet, and hippies and counterculture gurus of 1960s. In the 1980s, WE morphed into an early virtual community, The WELL (Whole Earth 'Lectronic Link), best known for its electronic bulletin boards, where John Cage and other luminaries posted writings (Paik, 1985). Some of Brand's associates contributed to founding Wired Magazine, the popular journal of techno-culture. Turner notes the specific influence of Kaprow's ideas on Brand: "Happenings offered a picture of a world where hierarchies had dissolved, where each moment might be as wonderful as the last, and where every person could turn her or his life into art" (Turner, 2006).

Such motivations call to mind what are now the tiresome and paradoxical rhetorics of creative emancipation that we hear from web 2.0 pundits, digital creatives and digital artists alike. There are contradictions inherent in the presumed origins and present day anti-establishment practices of new media that should indeed be subject to criticism, much as Kaprow's Happenings have been, such as for example: Were they really interactive, Kaprow having prescribed everything in advance? (Sandford, 1995) Why would non-art artists be so deeply concerned with the mainstream art world in the first place? Although talk of "freedom" may at times seem idealistic, tiresome or divergent, real creative, artistic and social diversification has been wrought by contemporary technologies. Although inconsistent, nonart and anti-form ideas were rendered consequential by what they countered: the neo-modernist art world of the early 1960s. Similarly, the military-industrial origins of new media technologies make them a much-needed vehicle for subversive attempts to open up information flow, increase participation and spark critical investigation. But even as we call into question the truth, potency or necessity of early conceptual art; even as we experience interactivity via technological affordances, we acknowledge their similarity of ambition and intent as an equivalent drive towards change, openness and interaction between and with people. It is this that gives both 1960s culture and contemporary new media art their common status as contrarian countercultures in the first place: "Anything less than paradox would be simplistic" (Kaprow, 1986).

\section{Burnham vs. Mcshine}

Exaggerating an idea set out by Charlie Gere (2005) we might posit 1970 as the year a face-off took place between art-and-technology and mainstream conceptual art (Gere, 2005). Two New York shows were mounted in this year which employed dissimilar models for the ways in which technology could be absorbed into mainstream contemporary art. Software, curated by Jack Burnham and installed at the Jewish Museum, employed a somewhat determinist software/ hardware metaphor in its overall design, as well as including works by engineers as well as artists. Work in the show used actual technological materials to show relations to comparable complex systems. Information, a concurrent exhibition curated by Kynaston McShine for the Museum of Modern Art, showed no works that were based in material technologies, but instead favoured entirely conceptual artists and approaches.

Luke Skrebowski has outlined how the systems theory upon which Burnham based his theory of art and the Software exhibition in the end became associated with "the command and control needs of a burgeoning postwar military-industrial complex" (Skrebowski, 2006). Skrebowski criticises Burnham's work for hinting at "but never comprehensively follow[ing] through on, a disarticulation of systems theory from its techno-industrial deployment. In so doing he only suggested the possibilities that systems theory might offer a critical art practice". The dominant narrative that emerges from this contest 


\section{artnodes}

http://artnodes.uoc.edu

Could This Be What It Looks Like? Lifelike Art...

for the hearts and minds of the early 1970s art world has Burnham's suggestions and possibilities retiring to the dust bins of history, and Burnham himself disappearing from the art world altogether (Skrebowski, 2006). Comforted by the sustained (and profitable) myth of the prominent, isolated, sheltered artist, mainstream artistic practice absorbed conceptual art into the culture industry of the late 70 s, 80 s and early 90 s.

\section{Could this be what it looks like? (A speculative conclusion)}

Artists and theorists still find themselves trying to make sense of the uncomfortable fit that new media and art-and-technology often make in the contemporary art world. The practice is as dispersed, heterogeneous and contrarian now as it has been in the past. But considering the lineage just traced, should this come as much of a surprise? Derived as it is from movements as radically anti-art and anti-institution as Kaprow's Happenings, Environments and Activities; as revisionist and fiercely independent as Stewart Brand's countercultural cyberculture; as utopian and confrontational to the object of Western Art in its distribution of creative agency as Burnham's Systems Art - we should be more astounded were art-and-technology to smoothly and comfortably merge itself into the mainstream and commercial art world.

It is likely that there is a resistant, countercultural strand of techno-social DNA which evolved through and into art-and-technology and new media practices. Many new media practitioners shyly admit to "hippie computer nerd" inclinations, in spite of themselves. Paul Slocum, net artist and founder of a seminal group-surfing blog bemoans the fact that "many artists I know, myself included, have idealistic tendencies and have really latched onto these internet philosophies of freedom (as in both speech and beer)" (Slocum, 2010). These are ideological standards rooted in the values of foregoing creative techno-cultures, which actively resisted the mainstream of their day. There are, of course, paradoxes to be picked at and on. Google's obliging motto, "Don't Be Evil", would seem in line with internet philosophies of freedom, yet its technologies form a new kind of institutional practice, underpinning mainstream culture. Exceptions also surface when new media artists do succeed commercially - but the vast majority of these artists do not.

Through sheer institutional momentum (at best) or a kind of cultural hegemony (at worst), the angel of mainstream art history tends to absorb the work of even its most revolutionary affiliates into an appropriative, linear narrative. The "intermedia" ideas posited by Dick Higgins in 1966, the opening up of formal media constraints and spatial restrictions of the gallery begun by Kaprow, and the Fluxus "forms" of games and kits as scores for open action within the everyday, have all been commandeered for exhibitions by institutional storytellers of an ideologically sympathetic, yet sales and box-officeconscious gallery and museum culture. One would be remiss not to acknowledge the profound and comprehensive nature of the 1960s countercultural message: a radical rethinking of the artist's position within society, and a radical questioning of the entire idea of art. As Kaprow noted, "Only when active artists willingly cease to be artists can they convert their abilities, like dollars into yen, into something the world can spend: play. [...] Gradually, the pedigree 'art' will recede into irrelevance" (Kaprow, 1961). Burnham was in accord, "In an advanced technological culture the most important artist best succeeds by liquidating his position as artist vis-a-vis society" (Burnham, 1968).

Returning to the presumed failure of art-and-technology in the early 70s, Gere writes, "Perhaps the real issue about art and technology was not that it failed, but rather that it succeeded too well", in that "much of what such art represented or sought to achieve was co-opted by the computer industry" (Gere, 2005). In a way, the techno-artistic avant-garde of the late 1960s has been vindicated by the development of information systems into aesthetic, multimedia, interactive and social tools. This success of art-and-technology makes plausible the hypothesis that the $700,000+$ daily users on 4chan's /b/ message board is an extension of this avant-garde - decentralised, anonymous and relational. Just as YouTube user "crinanthebrave" reconstitutes Scott-Heron's revolutionary anthem, technology-literate creative communities "create pathways through culture by reorganizing history to bring forward new ideas" and "merge everyday life with the aesthetic realm" (Troemel, 2010). As such, they remain true to the heritage of the countercultures from which art-and-technology sprang.

In a techno-scientific culture, an experience of the everyday is an experience of and through technology. Contemporary art-andtechnology practice, with its rebelliousness and affinities towards a broad range of expressive modes, is a counterculture - but with numerous cultures to counter. Commercial and industrial interests do not always sit well within culture that has grown used to independent production and creative freedoms. Likewise, the structures of the mainstream art world remain somewhat unreceptive to the diversified, collocated, and open structures that a technological art practice allows. Like the best art, the best new technologies always challenge convention. Productive frictions maintain the diversity of a creative domain, and "antagonism is a by-product of free choice and speech" (Troemel, 2010). Art-and-technology culture may one day cease its evasions of and tensions with a more mainstream art world, but we should hope that this day may never come.

\section{References}

BURNHAM, Jack (1968). Beyond Modern Sculpture: The Effects of Science and Technology on the Sculpture of This Century. London: Allen Lane/Penguin Press. 


\section{artnodes}

http://artnodes.uoc.edu

Could This Be What It Looks Like? Lifelike Art...

BURNHAM, Jack (1968). Systems Esthetics. Reprinted from Artforum. [Accessed: July 2011]. $<$ http://www.arts.ucsb.edu/faculty/jevbratt/readings/burnham_ se.html>

crinanthebrave (2009, 29 April). You Tube published "music video" for Gil Scott-Heron's The Revolution Will Not Be Televised [Accessed: July 2011]. $<$ http://www.youtube.com/watch?v=BS3Q0tbW4m0>

GERE, Charlie (2005). "Jack Burnham and the Work of Art in the Age of Real-time Systems". In: Get Real : Real Time + Art + Theory + Practice + History. New York: Braziller, pp. 149-164.

KAPROW, Allan (1986). Art Which Can't Be Art. [Accessed: July 2011]. $<\mathrm{http}$ ://readingbetween.org/artwhichcantbeart.pdf>

KAPROW, Allan (1971). The Education of the Un-Artist, Part I. Reprinted in: J. KELLEY (ed.) (1993). Allan Kaprow, Essays on the Blurring of Art and Life (1993). Berkeley: University of California Press.

KAPROW, Allan (1961). The Education of the Un-Artist, Part II. Reprinted in: J. KELLEY (ed.) (1993). Allan Kaprow, Essays on the Blurring of Art and Life. Berkeley: University of California Press.

PAIK, Nam June (1985). John Cage and Nam June Paik in Conversation. University of California San Diego. [Audio accessed: July 2011]. $<$ http://heavysideindustries.com/2010/10/nam-june-paik-inconversation-ucsd-1985/>

PENNY, Simon (1999, January). "Systems Aesthetics and Cyborg Art: the legacy of Jack Burnham". Sculpture Magazine.

RAMPLEY, Martin (2005, January). "Systems Aesthetics: Burnham and Others". Vector E-Zine. [Accessed: July 2011].

$<$ http://virose.pt/vector/b_12/rampley.html>
SANDFORD, M. R. (1995). Happenings and Other Acts. London / New York: Routledge.

SHANKEN, Edward (1999, November). "The House that Jack Built: Jack Burnham's Concept of 'Software' as a Metaphor for Art". Leonardo Electronic Almanac. Vol. 6, iss. 10.

SKREBOWSKI, Luke (2006, Spring). "All Systems Go: Recovering Jack Burnham's Systems Aesthetics". Tate Papers.

SLOCUM, Paul (2010). "New Media and the Gallery". Art Lies Contemporary Art Journal. Iss. 67. [Accessed: July 2011]. $<$ http://www.artlies.org/article.php?id=1993\&issue=67\&s=0>

SMITH, Stephen (2009). "The legendary godfather of rap returns". BBC News. [Accessed: July 2011].

$<$ http://news.bbc.co.uk/1/hi/programmes/newsnight/8362518. stm>

TROEMEL, Brad (2010, September). "What Relational Aesthetics Can Learn From 4Chan". [IMG MGMT] Art Fag City. [Accessed: July 2011].

$<$ http://www.artfagcity.com/2010/09/09/img-mgmt-whatrelational-aesthetics-can-learn-from-4chan/>

TURNER, Fred (2006). From Counterculture to Cyberculture: Stewart Brand, the Whole Earth Network, and the Rise of Digital Utopianism. Chicago: University of Chicago, p. 48.

WARDRIP-FRUIN, N.; MONTFORT, N. (2003). The New Media Reader. Boston: MIT Press, p. 83.

YoUNGBLO0D, Gene (1970). Expanded Cinema. Boston: Dutton, pp. $343-344$

\section{Recommended Citation}

ALLEN, Jamie (2011). "Could This Be What It Looks Like? Lifelike Art and Art-and-Technology Practice". In: Edward A. SHANKEN (Coord.). "New Media, Art-Science and Contemporary Art: Towards a Hybrid Discourse?" [online node]. Artnodes. No. 11, p. 74-79. UOC [Accessed: dd/mm/yy]. $<$ http://artnodes.uoc.edu/ojs/index.php/artnodes/article/view/artnodes-n11-allen/artnodes-n11allen-eng>

ISSN 1695-5951

\section{(c)}

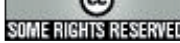

This article is - unless indicated otherwise - covered by the Creative Commons Spain Attribution 3.0 licence. You may copy, distribute, transmit and adapt the work, provided you attribute it (authorship, journal name, publisher) in the manner specified by the author(s) or licensor(s). The full text of the licence can be consulted here: http://creativecommons.org/licenses/by/3.0/es/deed.en. 


\section{artnodes}

http://artnodes.uoc.edu

Could This Be What It Looks Like? Lifelike Art...

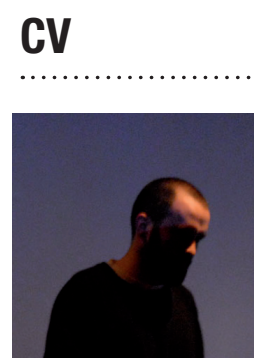

\author{
Jamie Allen \\ Culture Lab \\ Newcastle University \\ jamie@heavyside.net \\ http://heavyside.net/ \\ Culture Lab \\ Newcastle University \\ Grand Assembly Rooms, King's Walk \\ Newcastle Upon Tyne NE1 7RU
}

Jamie Allen likes to make things with his head and hands. These things often involve peoples' relationships to creativity, technology and resources - and mostly attempt to give people new, subversive and fun ways to interact with all of these. He works as Assistant Director of Culture Lab (Newcastle University, UK), where he leads the Digital Media course, teaches and develops projects. His projects and events have been featured in a number of media outlets, including Wired.com and the New York Times. He has been supported by international organizations, festivals and venues, including: Korea Foundation (KR), Issue Project Room (NYC), Sonic Circuits (DC), Nikolaj Copenhagen Contemporary Art Center (DK), FACT (UK), Transitio (MX), Arts Council England (UK), Northern Film and Media (UK), Arts Council Korea (Seoul), Eyebeam.org (NYC), The Canada Council for the Arts (CA), STEIM (NL), Baryshnikov Dance Foundation (NYC), Joyce Soho (NYC), The Lower Manhattan Cultural Council (NYC), Exit Art (NYC), Harvestworks (NYC), La Société des arts technologiques (MTL), Washington State University (USA), The University of British Columbia (CND), The Tisch School of the Arts (NYC), The Tank (NYC), Tonic (NYC), Vertexlist (NYC), Chelsea Art Museum (NYC), Mushroom Arts (NYC), Medianoche (NYC), The Bent Festival (NYC), The Edinburgh Festival (UK), The Glasgow School of Art (UK).

$\mathrm{He}$ is a PhD candidate with the European Graduate School (Media \& Communications).

\section{$\bullet$ UOC

